УДК 332.05

Вахович I.М., д.е.н., професор

Салівончик I.M., аспірант

Луцький НТУ

\title{
ТЕОРЕТИЧНІ АСПЕКТИ ФАКТОРНОГО ВПЛИВУ СТРУКТУРНОЇ МОДЕРНІЗАЦІЇ ЕКОНОМІКИ РЕГІОНУ
}

В статті розглянуто основні теорії економічного росту, сформовано визначальні фактори побудови теорій, які можна використати при аналізі взаємодії процесів розвитку й удосконалювання структурної модернізації економіки регіону.

Ключові слова: теорії, моделі економічного росту, фактори економічного розвитку, модернізація економіки.

Ваховыч И.М., Саливончик И.М.

\section{ТЕОРЕТИЧЕСКИЕ АСПЕКТЫ ФАКТОРНЫХ ВЛИЯНИЙ СТРУКТУРНОЙ МОДЕРНИЗАЦИИ ЭКОНОМИКИ РЕГИОНА}

В статье рассмотрены основные теории экономического роста, сформирован определяющие факторы построения теорий, которые можно использовать при анализе взаимодействия процессов развития и совершенствования структурной модернизации экономики региона.

Ключевые слова: теории, модели экономического роста, факторами экономического развития, модернизация экономики.

Vahovych I., Salivonchyk I.

\section{THEORETICAL ASPECTS OF FACTOR IMPACT STRUCTURAL MODERNIZATION OF ECONOMY REGIONAL}

In the article the basic theories of economic growth are considered, the determining factors of construction of the theories which can be used in the analysis of interaction of processes of development and improvement of structural modernization of economy of the region are formed. economy.

Keywords: theories, models of economic growth, factors of economic development, modernization of

Постановка проблеми у загальному вигляді i iï зв'язок 3 важливими науковими та практичними завданнями. Для сучасного етапу проблематиці розвитку економічних теорій та моделей присвячено багато досліджень. Зусиллями багатьох учених досягнуто розуміння сутності основних напрямів теорій економічного росту, у цьому процесі технічного прогресу, інститутів, змін у структурі виробництва. Але до сьогодення малодослідженим залишається питання факторного впливу структурної модернізації економіки.

Аналіз останніх досліджень, у яких започатковано вирішення проблеми. Питання теорій та моделей розвитку економіки досліджували зарубіжні вчені: У. Ростоу, Дж. Бортса, Х. Зіберта, Р. Солоу, Т. Свана, Г. Менк'ю, Д. Ромера, А. Уейла, Р. Барро, Х. Сало-і-Мартіна, Р. Харрода і Є. Домара, Р. Хола і Ч. Джонса, Г. Мюрдаль, А. Хіршман, Ф. Перру, Ж-Р. Будвіль, П. Потьє, Х. Річардсон, Дж. Фрідман, Й. Шумпетером, П. Самуельсона, В. Леонтьєв. Узагальнюючи вчених можна зазначити, що їхні концепції виходять $з$ постулатів теорії ринкової рівноваги.

Цілі статті. Дослідження факторного впливу структурної модернізації економіки.

Виклад основного матеріалу дослідження 3 повним обгрунтуванням отриманих наукових результатів. Досліджуюючи процес розвитку модернізації економіки, економісти приходили до різного розуміння його сутності, у результаті чого сформувалося кілька основних напрямів теорії економічного росту, які можна 
використати при аналізі взаємодії процесів розвитку й удосконалювання структурної модернізації економіки регіону:

1) модель лінійних стадій росту;

2) неокласична модель;

3) модель кумулятивної причинності;

4) модель структурних перетворень;

5) нова теорія економічного росту;

6) еволюційна теорія - універсальна циклічна модель.

Зведена інформація щодо напрямів моделей та теорій економічного росту представлена в таблиці 1.

Таблиця 1.

Еволюція напрямів та теорій економічного росту

\begin{tabular}{|c|l|}
\hline Модель/ Теорія & \multicolumn{1}{|c|}{ Визначальні фактори та умови побудови моделі/теорії } \\
\hline Модель лінійних & Фактори: \\
стадій росту & $\checkmark$ Традиційне суспільство \\
& $\checkmark$ Дозрівання передумов для ривка; \\
& $\checkmark$ Ривок до самопідтримуючого росту; Перехід до технологічної \\
& зрілості; \\
& $\checkmark$ Ера масового споживання \\
\hline Неокласична модель & Фактори: \\
& $\checkmark$ виробничий потенціал економіки, \\
& $\checkmark$ кількість і якість природних ресурсів, загальна чисельність і \\
& кваліфікація трудових ресурсів, \\
& $\checkmark$ запаси капіталу, рівень технологій \\
\hline Модель кумулятивної & Фактори: \\
причинності & $\checkmark$ спеціалізація і територіальний поділ праці, існування центрів росту \\
& $\checkmark$ формування системи центральних місць (агломерацій), \\
& $\checkmark$ дифузія нововведень \\
\hline Модель структурних & Фактори: \\
перетворень & $\checkmark$ міграція робочої сили із села в місто \\
& $\checkmark$ зростання виробництва й зайнятості у високотехнологічних галузях \\
\hline Нова теорія & «Конепція ендогенного розвитку» \\
економічного росту & Полягє в орієнтації насамперед на внутрішні чинники і механізми, які в \\
& сукупності здатні забезпечити саморозвиток і самовідтворення \\
& національних економічних систем \\
\hline Еволюційна теорія - & Циклічний розвиток галузевої структури економіки виходить з процесу \\
універсальна циклічна & поширення нововведень, який супроводжується виробництвом нових \\
модель & товарів \\
\hline
\end{tabular}

Зазначені моделі розроблялися з метою визначення оптимального співвідношення між факторами економічного розвитку, умов, що забезпечують його бажані темпи i стабільність, найважливіших пропорцій між елементами макроекономічного відтворення. Перша модель, розглядає процес розвитку як серію послідовних стадій економічного росту, через які повинна пройти будь-яка країна. Згідно з теорією найбільш відомого представника цього напряму У. Ростоу, економічний устрій будь-якого суспільства може бути охарактеризовано в межах одного з наступних етапів розвитку: традиційне суспільство; - дозрівання передумов для ривка; ривок до самопідтримуючого росту; - перехід до технологічної зрілості; - ера масового споживання. Всі розвинені країни, за цією теорією, пройшли через стадію ривка до самопідтримуючого росту, у той час як країни, що розвиваються перебувають або на стадії традиційного суспільства, або стадії дозрівання передумов для ривка. Перейти ж до ривка вони можуть тільки за умов здійснення заходів щодо оптимізації структури економіки, у тому числі за рахунок здійснення достатніх інвестицій з метою прискорення економічного росту.[1, с. 338] Неокласичні моделі розвитку економіки розроблені в роботах Дж. Бортса, Х. Зіберта, Р. 
Солоу, Т. Свана, Г. Менк'ю, Д. Ромера, А. Уейла, Р. Барро, Х. Сало-і-Мартіна, Р. Харрода і Є. Домара, Р. Хола і Ч. Джонса [2, с. 1521-1539]. Узагальнюючи неокласиків можна зазначити, що їхні концепції виходять $з$ постулатів теорії ринкової рівноваги. Ринкова мобільність факторів призводить до повернення економічної системи у стан рівноваги структурних елементів, яка формує більш високий рівень розвитку. Основними факторами розвитку виступають перш за все, виробничий потенціал економіки, кількість i якість природних ресурсів, загальна чисельність і кваліфікація трудових ресурсів, запаси капіталу, рівень технологій. Економічний механізм розвитку за допомогою інвестицій описується неокласичною моделлю Харрода-Домара. Дана модель враховує тільки капітал як єдиний фактор розвитку, що в свою чергу синтезує в собі функціонування всіх інших. Із проведеного вченими аналізу випливає, що: 1) економічний розвиток передбачає не просто підтримку поточного рівня інвестицій, a їх збільшення, що розглядаються як «спонукальні поштовхи» або «нові імпульси» до розвитку; 2) зріст національного доходу відображається виключно функцією нагромадження капіталу; 3) капіталомісткість не залежить від співвідношення цін і виробничих факторів, а визначається лише технічними факторами виробництва. Таким чином, для забезпечення економічного розвитку в країні необхідно постійне заощадження й інвестування певної частки ВНП. Саме так У. Ростоу та його послідовники визначають умови для ривка. Країни, які здатні зберігати 15-20\% ВНП, можуть розбудуватися швидше тих, у кого норми заощаджень нижче. Збільшення заощаджень та інвестицій $є$ необхідною, але не достатньою умовою розвитку й наступного росту. Необхідні структурні, інституціональні й культурні передумови, які полягають у розвиткові товарних і грошових ринків, підготовці кваліфікованих кадрів, культурі підприємництва, ефективній адміністративній системі. Разом 3 тим протилежних поглядів на архітектоніку розвитку економіки дотримувалися представники теорій кумулятивної причинності Г. Мюрдаль, А. Хіршман, Ф. Перру, ЖР. Будвіль, П. Потьє, Х. Річардсон, Дж. Фрідман [3, с. 767]. В основі моделей кумулятивної причинності знаходиться положення про нерівномірний розвиток модернізації економіки в умовах вільної конкуренції. Основними факторами розвитку визнаються спеціалізація і територіальний поділ праці, існування центрів росту, каналів його поширення в національному економічному просторі, формування системи центральних місць (агломерацій), дифузія нововведень, постійна віддача від масштабів виробництва. Найбільше визнання серед кумулятивних моделей отримала конструкція теорії полюсів росту, обгрунтована Ф. Перру, і заснована на положеннях вчення про інноваційний розвиток економіки Й. Шумпетера. В іiі основі лежить уявлення про провідну роль галузевої структури економіки, і в першу чергу, галузей, що лідирують та створюють нові товари і послуги. Вона розвиває теорію центральних місць, використовуючи більш сучасні досягнення економічної науки (зокрема, метод «витрати - випуск» В. Леонтьєва) [4, с. 82- 89]. В межах теорії структурних перетворень, економічний розвиток розглядається в контексті переходу від традиційного господарства до високотехнологічних галузей. Двохсекторна модель А. Льюіса виходить 3 положення, що основними факторами економічного розвитку виступають: міграція робочої сили із села в місто та зростання виробництва й зайнятості у високотехнологічних галузях. Таким чином їх розвиток детермінується зростом реінвестування, яке відбувається на основі накопичення капіталу, що викликає збільшення обсягів виробництва, міграції, зайнятості. Саме після того як уся зайва сільська робоча сила буде поглинена новими галузями промисловості процес збільшення зайнятості й самопідтримуючого росту припиняється. Однак історичний характер моделі пояснює те, що вона не враховує сучасні інституціональні й економічні реалії, такі як відсутність надлишків робочої сили в селі, міське безробіття, що частково детермінується розвитком технологій [5]. В межах структуралістської теорії економічного розвитку, була сформована трифазна модель Х. Ченери. Основними 
чинниками структурної модернізації економіки визначаються: розвиток технологій, зростаючі потреби суспільства, відкритість національної економіки, нагромадження капіталу, зростання рівня освіти. Модель відображає фази навздогінного розвитку країн, що розвиваються. Засновуючись на положенні неокласичної теорії про мобільність факторів, основним 3 яких є капітал. Тобто автор моделі розкриває логіку послідовної зміни макроекономічних пропорцій: збільшення заощаджень, вирівнювання середньої схильності до заощаджень i норми інвестицій, приріст іноземних інвестицій, перерозподіл інвестиційних потоків, забезпечення випереджального зростання експорту у порівнянні з темпами росту ВНП [6, с. 310-316 ]. Слід зауважити на загальній рисі моделей структуралістів, яка полягає у визнанні необхідності державного впливу на економічні процеси розвитку, за певних умов адаптації, вона може бути використана й у сучасній дійсності. На противагу структуралістам, за скорочення державного втручання в економіку виступали представники неокласичного напрямку в економічній думці, такі як П. Бауэр, М. Джонсон, Д. Саймон. Вони наголошували на необхідності забезпечення відкритості економіки, приватизації неефективних державних підприємств і позитивній ролі вільних ринків. Не можливо не відзначити й дослідження відомих представників неокласичного синтезу - економістів П. Самуельсона і В. Леонтьєва. Самуельсона вважають автором теорії виявлених переваг споживачів. Саме прагнучи досягти максимуму корисності, споживач зіставляє варіанти й зупиняється на кращих з них у відповідності зі своїми уподобаннями. Самуельсон аналізує, яким шляхом можна максимізувати виробництво продуктів певної структури, оскільки у випадку структурних змін відбувається незбалансований ріст окремих галузей і виробництв, що $\epsilon$ гальмом для стійкого економічного розвитку. Зміна обстановки на ринку змінює характер попиту. Більш особливу актуальність це питання приймає у зв'язку 3 економічною ситуацією в нашій країні. У вітчизняній економіці утворився найсильніший розрив між можливим і реально наявним сукупним попитом, що виражається в значному недовантаженні в багатьох навіть важливих галузях, у тому числі легкої промисловості, машинобудуванні, сільському господарстві. На відміну від П. Самуельсона, В. Леонтьєв проаналізував систему взаємозв'язків в економіці як єдине ціле. Інструментом аналізу стала таблиця балансів, що ділить господарство на кілька десятків галузей. Ця теоретична модель, що одержала назву «витрати - випуск», послужила основою для побудови багатогалузевої моделі економіки США. Розробка динамічних моделей міжгалузевого балансу використовувалася і для аналізу наслідків різних варіантів економічної політики. Міжнародна економічна динаміка кінця 80-х початку 90-х років відзначалася збільшенням диференціації соціально-економічного розвитку між різними країнами світу. Відповідна тенденція, ускладнила застосування традиційних теорій для аналізу економічних процесів. В результаті з'явився новий підхід щодо вирішення проблем розвитку економіки - концепція ендогенного розвитку (нова теорія розвитку). Головна особливість моделі ендогенного розвитку полягає в орієнтації насамперед на внутрішні чинники і механізми, які в сукупності здатні забезпечити саморозвиток $\mathrm{i}$ самовідтворення національних економічних систем. Важлива роль при цьому відводиться активній економічній політиці, яка покликана сприяти максимальному залученню усіх наявних у країні ресурсів і механізмів задля розвитку власної національної економічної системи та іiі кількісного і якісного удосконалення. Незважаючи на подібність нової теорії розвитку й неокласичних теорій, між ними існують істотні відмінності. Технічний прогрес вже не є єдиною можливою причиною економічного росту в довгостроковій перспективі. Крім того, нова теорія розвитку виходить з відсутності автоматичного вирівнювання темпів розвитку між країнами вони залишаються незмінними й залежать від рівня нагромаджень і розвитку техніки в даній країні. Технології підвищують прибутковість інвестицій, тому розвиненим країнам вдається підтримувати швидкі темпи росту, а не боротися зі зменшенням прибутковості, на що вказує традиційна теорія. Тривале гальмування темпів росту в країні призводить 
до ще більш сильного ії відставання від розвинених країн за рівнем доходу на душу населення. Розрив між розвиненими країнами, та країнами що розвиваються збільшується в результаті протиприродного переливу капіталів. Потенційно висока рентабельність інвестицій у країнах, що розвиваються втрачає свою привабливість через низький рівень інвестицій у людський капітал, інфраструктуру та НДДКР. Країни, що розвиваються отримують від інвестицій набагато менше вигід, ніж економічнорозвинені країни. В межах зазначеної у переліку еволюційної теорії, циклічний розвиток галузевої структури економіки виходить 3 процесу поширення нововведень, який супроводжується виробництвом нових товарів, застосуванням нових технології й нової техніки, більш ефективним використанням вже відомих матеріалів, освоєнням нових ринків збуту, переходом до більш раціональних форм організації та методів управління. Матеріальну базу зміни структури, за Й. Шумпетером становлять кластери нововведень, що несуть в економіку заряд технологічного прогресу. Перехід на нові технології обумовлює структурні зрушення, оскільки змінюється поділ праці усередині виробничих ланок, між галузями, між територіями, між секторами відтворення суспільного продукту. Виділяються наступні фази циклу інноваційних перетворень: 1) початок циклу, що характеризується появою важливого технологічного нововведення, що призводить до появи прибутків у інноватора - в термінах теорії довгих хвиль, початок зростаючої хвилі; 2) середина циклу, масоване поширення нових технологій, пов'язаних з інноваціями, на всі галузі і сектори економіки; 3) закінчення циклу, поступове зниження ефективності інновацій, вичерпання можливостей підвищення ефективності в рамках оновленої структури, спадаюча частина довгої хвилі. Галузева структура економіки регіону розвивається у відповідності із зазначеною логікою: 1) початок циклу, поява інновацій, зародження нових галузей; 2) середина циклу, поширення технологічних перетворень на традиційні галузі, розширення нових галузей; 3) закінчення циклу, заміна колишніх технологій новими, завершення перетворень галузевої і технологічної структури [7]. Таким чином, сутність економічного розвитку регіону полягає не стільки в нагромадженні капіталу та збільшенні додаткової робочої сили, скільки в їхній диверсифікації до більш ефективних сфер економічної діяльності.. Не монетарні процеси, а еволюція попиту та пропозиції на нові продукти, нові технології, способи організації виробництва формує бізнес-цикли в економіці. Для кожної стадії розвитку модернізації економіки регіону характерні свої особливості економічного росту. На доіндустріальній стадії спостерігався екстенсивний економічний зріст за рахунок розширення використання природніх ресурсів (праця, земля). Індустріальна стадія розвитку характеризується інвестиційним ростом ( як екстенсивним, так і інтенсивним). Постіндустріальна стадія характеризується інноваційним характером економічного розвитку. За умов постіндустріального розвитку, основою процесу структурної перебудови економіки необхідно вважати технологічні зрушення, детерміновані науково-технічним прогресом. Поняття «технологія» безпосередньо пов'язане зі знаннями щодо організації виробництва матеріальних благ. Воно було введено до наукового обігу у 70-х роках XVIII ст. німецьким дослідником Й. Бекманом. Стосовно індустріальної стадії розвитку економіки вважається, що «технологія» - спосіб перетворення різноманітних ресурсів у процесі виготовлення продукції, обробки та переробки матеріалів, складання готових виробів, контролю якості та управління. Починаючи з промислового перевороту середини XVIII ст. позиція країни у світовій економіці та іiі політична вага у світі, значною частиною визначаються ступенем іiі технологічного розвитку. Технології являють собою результат застосування наукових знань. Рівень технологічного розвитку визначає застосовувані суспільством економічні ресурси. Так, на до індустріальній стадії ними переважно $\epsilon$ земля i праця. На індустріальній стадії разом 3 появою індустріальних технологій на перше місце висувається промисловий капітал, а потім йдуть праця і земля. На постіндустріальній стадії, коли з'являються інформаційно-комунікаційні технології, в якості головного 
ресурсу виступає інформація. Також необхідно зауважити, що інформація як економічний ресурс існувала на всіх стадіях розвитку суспільства. Історія інформаційного ресурсу нараховує стільки ж століть, скільки й наука, але саме на інформаційній стадії вона стає головним ресурсом економіки. Вплив науково-технічного прогресу проявляється у модифікації i модернізації економічної структури, започаткуванні нових виробництв, галузей, секторів економіки. Три технологічні революції спричинили принципові зміни в організації виробництва. Перша - спиралася на енергію вугілля й пари, друга - була революцією електрики й нафти, третя (інформаційна революція) - пов'язана 3 мікроелектронікою, біотехнологією, ядерною енергією, що знаменує етап формування й розвитку моделі постіндустріального суспільства. Процеси технологічного відтворення в постіндустріальну (інформаційну) епоху характеризуються експонентним прискоренням, а інтернаціоналізація НТП робить структуру економіки ще більш динамічною. Підвищується інформаційна ємність структури економіки. Цей показник поступово стає одним з показників ефективності функціонування економіки. Здатність економіки продукувати нову інформацію, швидкість та інтенсивність цього процесу стають найважливішими умовам прогресивних або регресивних структурних зрушень. За оцінками багатьох дослідників, одним з головних факторів структурної модернізації економіки регіону виступає військовий фактор, під яким ми розуміємо зріст військових витрат, розвиток військовопромислового комплексу, мілітаризацію економіки. Історичний аналіз розвитку державних структур показує, що необхідність забезпечення військових потреб, завжди виступала каталізатором економічного розвитку. Наприклад, перебудова армії та флоту за часів Петра I, спричинила розвиток мануфактурного виробництва та зміну структури економіки. Безпрецедентна за масштабами індустріалізація в СРСР багато в чому в якості основи, спиралася на розвиток військово-промислового комплексу Дійсно, саме необхідність вирішення багатьох військових (оборонних) завдань у різних країнах спричиняла появу безлічі винаходів, які згодом використовувалися у секторі економіки, прискорюючи його розвиток. Третій фактор впливу на структурну перебудову економіки регіону полягає у характері співвідношення ринкових та державних механізмів регуляції. Взаємозв'язок ринку і технологічного розвитку проявляється в тому, що ринок виникає спонтанно на основі суспільного поділу праці, який у свою чергу визначається рівнем існуючого технічного розвитку. Поділ праці призводить до розвитку процесів обміну результатами діяльності, тобто росту обсягів ринку, що, за теорією А. Сміта, у свою чергу, підсилює поділ праці. Ринок впливає на структуру економіки наступними чинниками. По-перше, сукупність ринків і ринкових відносин утворює каркас ринкової економіки. По-друге, ринок сприяє диверсифікації праці і капіталу з одних галузей i секторів економіки в інші. Таким чином, забезпечується мобільність факторів виробництва, від чого залежить гнучкість і своєчасність перебудови структури економіки. По-третє, умови ринкової конкуренції спонукають економічних суб'єктів до ефективного використання всіх видів економічних ресурсів, впровадження нових технологій, забезпечення високого доходу на вкладений капітал. По-четверте, стан i структура ринку визначають потреби у розвиткові окремих видів виробництв, галузей, секторів. По-п'яте, фінансовий ринок впливає на зміни в галузевій, відтворювальній структурі економіки, направляючи кредити й інвестиції в найбільш ефективні з погляду економічної віддачі галузі. По-шосте, ринок праці визначає багато в чому галузеву, технологічну й територіальну структуру економіки. Четвертим фактором модернізації структури економіки регіону виступає глобалізація. Європейська Комісія розглядає глобалізацію як «процес зростаючої взаємозалежності між ринками й виробництвом різних країн під впливом обміну товарів і послуг, а також фінансових і технологічних потоків».

Висновки: Таким чином, розглянуто фактори впливу структурної модернізації економіки, що характеризуються взаємозалежністю економік різних країн, посиленням 
міжнародної торгівлі, впливу ТНК, глобального фінансового капіталу. При цьому світова торгівля, транскордонні інвестиції зростають швидше, ніж світове виробництво, що ще тісніше зв'язує економіки між собою. Основними напрямами глобалізації визнаються: фінансово-банківська, інформаційна, інноваційна сфери. Переваги в економічному розвиткові одержують ті держави, що мають відповідні ресурси та направляють їх на розвиток та посилення своїх переваг.

\section{Список бібліографічного опису:}

1. Ростоу У. Стадии экономического роста (некоммунистический манифест) Нью-Йорк-М.: Наука, 1981. 338 с.

2. Пилипенко И.В. Анализ основных зарубежных теорий конкурентоспособности стран и регионов в современном мировом хозяйстве. Известия АН. Серия географическая. 2003. № 6. С. 1521-1539.

3. Мюрдаль Г. Современные проблемы «третьего мира». Драма Азии. Пер. с англ. / Общ. ред. д.э.н., проф. Р.А.. М.: Изд-во «Прогресс», $1972.767 \mathrm{c}$.

4. Бавико О. Бізнес-навігатор: Науково-виробничий журнал. Херсон: МУБіП. 2012. № 27. С. $82-89$.

5. Lewis A., Ульяновского.Є. Проблема сумісності завдань максимілізації темпів росту національної економіки та мінімізації міжрегіональної диференціації. Manchester School. 1954. 22 Mау.

6. Chenery H.V. The structuralist approach to development policy. American association Papers and Proceedings. 1975. № 65. P. 310-316.

7. Schumpeter J., Clemence R. Essays on economic topics. N. Y.: Kennikat Press, 1969.

\section{References:}

1.Rostow U. (1981). Stadyy эkonomycheskoho rosta (nekommunystycheskyi manyfest) [Stages of economic growth (noncommunist manifesto)]. [in Russian]

2.Pylypenko Y.V. (2003) Analyz osnovnыkh zarubezhnыkh teoryi konkurentosposobnosty stran y rehyonov v sovremennom myrovom khoziaistve [Analysis of the main foreign theories of the competitiveness of countries and regions in the modern world economy]. Yzvestyia AN. Seryia heohrafycheskaia - Izvestia AN. Geographical Series, № 6 1521-1539. [in Russian] 3.Myrdal G. (1972) Sovremennыe problemы «treteho myra» [Modern problems of the "third world"]. Publishing house "Progress".[in Russian]

4.Bavyko A. (2012) Biznes-navihator: Naukovo-vyrobnychyi zhurnal.[Business Navigator: Scientific Production Magazine]. Kherson: MUBiP, 82- 89. [in Ukrainian].

5.Lewis A., Ulyanovsky E. (1954) Problema sumisnosti zavdan maksymilizatsii tempiv rostu natsionalnoi ekonomiky ta minimizatsii mizhrehionalnoi dyferentsiatsii [The problem of compatibility of tasks to maximize the growth rate of the national economy and minimize interregional differentiation]. Manchester School.

6.Chenery H.(1975) The structuralist approach to development policy. [American association Papers and Proceedings], 310316.

7.Schumpeter J., Clemence R.(1969) Essays on economic topics. N. Y.: Kennikat Press.

УДК 332.1:332.834

Заблоцька І.Л.

Луцький національний технічний університет

\section{НАПРЯМКИ ПОКРАЩЕННЯ ВИКОРИСТАННЯ ФІНАНСОВО-ЕКОНОМІЧНИХ МЕХАНІЗМІВ РОЗВИТКУ ЖИТЛОВОГО БУДІВНИЦТВА В РЕГІОНАХ УКРАЇНИ}

В статті розкрито проблеми фінансування розвитку житлового будівництва в регіонах України. Узагальнено напрямки покращення використання фінансово-економічних механізмів розвитку житлового будівництва в регіонах України. Розкрито організаційні засади формування стратегії фінансовоекономічного забезпечення розвитку житлового будівництва в регіонах. Рекомендовано механізм запровадження комбінованого фінансування розвитку житлового будівництва в регіонах. Запропоновано державно-приватне партнерство як інструмент забезпечення розвитку житлового будівництва в регіонах.

Ключові слова: регіональна політика, забезпечення житлом населення, фінансово-економічні механізми, стратегія розвитку регіону, комбіноване фінансування, державно-приватне партнерство.

\section{Zablotska I.}

\section{WAYS TO IMPROVE THE USE OF FINANCIAL AND ECONOMIC MECHANISMS FOR HOUSING CONSTRUCTION DEVELOPMENT IN REGIONS OF UKRAINE}

The article deals with the problems of financing the development of housing construction in regions of Ukraine. The ways of improving the use of financial and economic mechanisms for housing development in the regions of Ukraine are summarized. The organizational principles of forming the strategy of financial and economic support for the development of housing construction in the regions have been determined. The mechanism of 